\title{
TbSAXO is a MAP6-related protein involved in motility of Trypanosoma brucei flagellum
}

\author{
M Bonhivers ${ }^{1,2^{*}}$, D Dacheux ${ }^{1,2,3}$, N Landrein ${ }^{1,2}$, M Thonnus $^{1,2}$, G Gilbert ${ }^{2}$, A Sahin ${ }^{1,2}$, H Wodrich ${ }^{1,2}$, DR Robinson ${ }^{1,2}$ \\ From First International Cilia in Development and Disease Scientific Conference (2012) \\ London, UK. 16-18 May 2012
}

The microtubules (MTs) of most vertebrate tissue cells will disassemble at low temperature, but some remain cold-stable or resistant to drugs such as nocodazole. It has been shown that MT cold- and nocodazole-resistance is largely due to the association with the class of Microtubule Associated Proteins (MAP) known as MAP6 (previously named STOP for Stable Tubule Only Polypeptide) [1]. MAP6 proteins are expressed only in vertebrates, and have been localized in neurons, astrocytes, oligodendrocytes, fibroblasts, and several tissues. In eukaryotes, the MT-based organelles centrioles, cilia and flagella MT have cold-resistant MTs, but, so far, MAP6 proteins have not been characterized in these organelles. We have recently identified TbSAXO (for Stop AXOneme), a novel flagellar protein in the protozoan parasite Trypanosoma brucei. We show here that TbSAXO is a microtubule stabilizing protein with properties similar, upon cold and nocodazole treatment, to those of the microtubule-stabilizing $\mathrm{Mn}$ domains of the MAP6 proteins, thus identifying the first MAP6-related protein in a protozoan. Further, we demonstrate, in the parasite, that TbSAXO is an axonemeassociated protein, which plays a role in flagellum motility. We also show that TbSAXO is the first member of a group of MAP6-related proteins (that we named SAXO proteins) present only in organisms with centrioles / cilia / flagella and ranging from protozoa to mammals, suggesting potential roles of the SAXO proteins in cilia and flagella function.

http://mcmp.aquitaine.cnrs.fr/mfp/team_bct_en.php

\section{Author details}

${ }^{1}$ CNRS, Microbiologie Fondamentale et Pathogenicite, UMR-5234, France. ${ }^{2}$ University of Bordeaux, Microbiologie Fondamentale et Pathogenicite,

\footnotetext{
* Correspondence: melanie.bonhivers@u-bordeaux2.fr

${ }^{1}$ CNRS, Microbiologie Fondamentale et Pathogenicite, UMR-5234, France

Full list of author information is available at the end of the article
}

UMR-5234, France. ${ }^{3}$ Institut Polytechnique de Bordeaux, Microbiologie Fondamentale et Pathogenicite, UMR-5234, France.

Published: 16 November 2012

Reference

1. Bosc C, Andrieux A, Job D: STOP proteins. Biochemistry 2003, 42:12125-12132.

doi:10.1186/2046-2530-1-S1-P16

Cite this article as: Bonhivers et al: TbSAXO is a MAP6-related protein involved in motility of Trypanosoma brucei flagellum. Cilia 2012 1(Suppl 1):P16.
Submit your next manuscript to BioMed Central and take full advantage of:

- Convenient online submission

- Thorough peer review

- No space constraints or color figure charges

- Immediate publication on acceptance

- Inclusion in PubMed, CAS, Scopus and Google Scholar

- Research which is freely available for redistribution

Submit your manuscript at www.biomedcentral.com/submit
() Biomed Central
C Biomed Central

(0) 2012 Bonhivers et al; licensee BioMed Central Ltd. This is an Open Access article distributed under the terms of the Creative Commons Attribution License (http://creativecommons.org/licenses/by/2.0), which permits unrestricted use, distribution, and reproduction in any medium, provided the original work is properly cited. 